\title{
The identification and determination of toxin genes of Vibrio strains causing hemorrhagic disease on red drum (Sciaenops ocellatus) using PCR
}

\author{
Pham Thi Hai Yen ${ }^{1}$, Nguyen Quang Linh ${ }^{1,2^{*}}$ ald and Nguyen Duy Quynh Tram
}

\begin{abstract}
Data were collected from 30 strains of Vibrio and sampled on different organs (brain, hemorrhagic site and digestive tract) of Sciaenops ocellatus infection. The results showed that the nucleotide sequences $16 \mathrm{~S}$ rRNA region are highly similar to those of $V$. alginolyticus, V. azureus, V. fluvialis, V. natriengens and V. orientalis, which were published on Genbank and other, ranging from 98.05 to 100\%. The digestive tract has the most common Vibrio strains (V. alginolyticus [16] V. azureus [7] and V. fluvialis). Thereout, 25 of 30 strains of Vibrio contained 1 to 3 toxin genes, except $V$. parahaemolyticus. Six parameters were used to measure the DNA polymorphism of 33 homologous DNA sequences in this Vibrio bacteria population. The results indicated that number of separate polymorphic sites $(S)$, total number of mutant sites (Eta), number of haplotype (h), haplotype diversity $(\mathrm{Hd})$, average number of nucleotide differences (k), nucleotide diversity (Pi) were 98 (S), 103 (Eta), 9 (h), $0.887 \pm 0.032(\mathrm{Hd}), 25.789(\mathrm{k})$ and 17.980 × 10-3 $\pm 0.003(\mathrm{Pi})$, respectively $(P<0,05)$. The $G+C$ content above 1434 sites positions of nucleotide sequences accounted for 0.542 . The phylogenetic tree showed that these strains are divided into six groups. As observed, the appearance of isolated Vibrio on 3 organs of fish (S. ocellatus) hemorrhagic are V. azureus (27,67\%), V. alginolyticus (50\%), V. orientalis (6,67\%) and V. fluvialis (16,67\%). Through this result, we found that the diversity of Vibrio species that appeared on the red drum was used in the 16S rRNA region and the presence of toxin genes in these Vibrio species.
\end{abstract}

Keywords: Sciaenops ocellatus, TDH, TRH, TLH, ToxR, Toxin gene, Vibrio

\section{Introduction}

More than 100 Vibrio spp. have been reported and are predominantly associated with a variety of marine, estuarine, or other aquatic habitats (Janda 2015). Red drum (Sciaenops ocellatus) was originally discovered in the Atlantic Ocean and the Gulf of Mexico; it was introduced into China in 1991, and since then, it has been cultured extensively in several provinces in China (Zhang and Sun 2011). In recent years, red drum (S. ocellatus) mortalities have

*Correspondence: nguyenquanglinh@hueuni.edu.vn; phamthihaiyen@hueuni.edu.vn

${ }^{1}$ University of Agriculture and Forestry, Hue University, Hue 530000, Vietnam Full list of author information is available at the end of the article been associated with Streptococcus iniae infection (Eldar et al. 1999), (Mmanda et al. 2014). Seven Vibrio strains (including $V$. vulnificus HM-TA-D2-L2-V2; $V$. vulnificus HM-TA-G2-V1-D2; V. brasiliensis HM-X-13/6; V. cholerae V-13/6; V. parahaemolyticus HM-17/6; V. cholerae HM-V$13 / 6$ and $V$. vulnificus HM-X-13/6) causing hemorrhagic disease in red drum (S. ocellatus) had only the th gene, and none of the Vibrio strains had tdh and trh genes (Quang et al. 2020). The research identified this fish (S. ocellatus) viperin gene (SoVip) and analyzed its expression in relation to bacterial challenge. The complete SoVip gene is $2570 \mathrm{bp}$ in length and contains six exons and five introns. The open reading frame of $1065 \mathrm{bp}$ is flanked by a 50 untranslated 
region (UTR) of $34 \mathrm{bp}$ and a $30 \mathrm{UTR}$ of $350 \mathrm{bp}$ and the fish pathogen Edwardsiella tarda but is downregulated by the fish pathogens Listonella anguillarum and Streptococcus iniae (Dang et al. 2010). Toxin gene neutrality was tested by three methods (Tajima's D test- Methods for sequence analysis of candidate genes obtained; Fu and Li's $\mathrm{D}^{*}$ and $F^{*}$ test, Fu's Fs-statistic P values being significant or not), (Tajima 1989), (Fu and Li 1993) and (Fu 1995), they indicated an excess of low frequency polymorphisms relating to expectation, evidence for a deficiency of alleles, as expected from a recent population bottleneck and the evolution of the studied 30 strains bacteria Vibrio, was balancing selection, sudden contraction, rare alleles appeared in populations with low frequency. The studied population had a few individuals showing large differences in comparison with other individuals. The study aims to identify and determine toxin genes in Vibrio infected red drum; hence, an understanding of Vibrio spp. infected on fish to cause Vibriosis in aquatic animals in brackish and marine water.

\section{Materials and methods Collection of fish disease}

In this study, data were collected from the field and stored at $-20{ }^{\circ} \mathrm{C}$, and we used thirty strains of bacteria with different morphologies isolated from three different organs in fish (S. ocellatus) that have hemorrhagic disease (Fig. 1) in Thua Thien Hue Province, Vietnam, based on medium TCBS (thiosulphate citrate bile salt sucrose).

\section{Total DNA extraction method}

The DNA extraction method presented in this paper is an improved method of phenol/chloroform extraction according to the method of (Neumann et al. 1992). We eliminated the step to use SDS/lysozyme or proteinase K and extraction of cells directly by phenol. To extract the DNA from bacteria isolated from hemorrhagic disease in fish, a $1 \mathrm{~mL}$ cell suspension was centrifuged at $8.000 \mathrm{rpm}$ for $2 \mathrm{~min}$ for the collection of pellet cells. After removing the supernatant, the cells were washed with $400 \mu \mathrm{l}$ STE buffer $(100 \mathrm{mM} \mathrm{NaCl}, 10 \mathrm{mM}$ Tris/HCl, $1 \mathrm{mM}$ EDTA, $\mathrm{pH}$ 8.0) twice and then centrifuged at $8000 \mathrm{rpm}$ for $2 \mathrm{~min}$. The pellets were resuspended in $200 \mu \mathrm{l}$ TE buffer (10 mM Tris/HCl, $1 \mathrm{mM}$ EDTA, $\mathrm{pH}$ 8.0). After this, $100 \mu \mathrm{l}$ Tris-saturated phenol $(\mathrm{pH}$ 8.0) was added to these tubes, followed by a vortex-mixing step of $60 \mathrm{~s}$. The samples were subsequently centrifuged at $13.000 \mathrm{rpm}$ for $5 \mathrm{~min}$ at $4{ }^{\circ} \mathrm{C}$ to separate the aqueous phase from the organic phase. A total of $160 \mu \mathrm{l}$ of the upper aqueous phase was transferred to a clean $1.5 \mathrm{ml}$ tube. Forty microliters of TE buffer was added to $200 \mu \mathrm{l}$, mixed with $100 \mu \mathrm{l}$ of chloroform and centrifuged for $5 \mathrm{~min}$ at $13,000 \mathrm{rpm}$ at $4{ }^{\circ} \mathrm{C}$. The lysate was purified by chloroform extraction until a white interface was no longer present; this procedure might have to be repeated two to three times. A total of $160 \mu \mathrm{l}$ of the upper aqueous phase was transferred to a clean $1.5 \mathrm{ml}$ tube. Then, $40 \mu \mathrm{l} \mathrm{TE}$ and $5 \mu \mathrm{l}$ RNase (at $10 \mathrm{mg} / \mathrm{ml}$ ) were added and incubated at $37{ }^{\circ} \mathrm{C}$ for $10 \mathrm{~min}$ to digest RNA. Then, $100 \mu \mathrm{l}$ chloroform was added to the tube, mixed well and centrifuged for $5 \mathrm{~min}$ at $13.000 \mathrm{rpm}$ at $4{ }^{\circ} \mathrm{C}$. Then, $150 \mu \mathrm{l}$ of the upper aqueous phase was transferred to a clean $1.5 \mathrm{ml}$ tube. The aqueous phase contained purified DNA and was directly used for the subsequent experiments or stored at $20{ }^{\circ} \mathrm{C}$. The purity and yield of the DNA were assessed spectrophotometrically by calculating the $\mathrm{A}_{260} / \mathrm{A}_{280}$ ratios and the $\mathrm{A}_{260}$ values to determine protein impurities and DNA concentrations according to (Neumann et al. 1992).

\section{Determination of toxin gene}

The presence of toxin genes in Vibrio spp. strains was determined through the presence of genes encoding toxic proteins $(t l h, t d h$, trh and toxR), which are based on specific primers for these genes (Table 1). PCR procedure: $50 \mathrm{ng}$ of total DNA, 10 pmol of each primer, $25 \mu \mathrm{l}$ PCR master mix $2 \times(2.4 \mathrm{mM}$ dNTPs each, 0.3 units Taq DNA polymerase, Promega, USA), and sterile distilled water
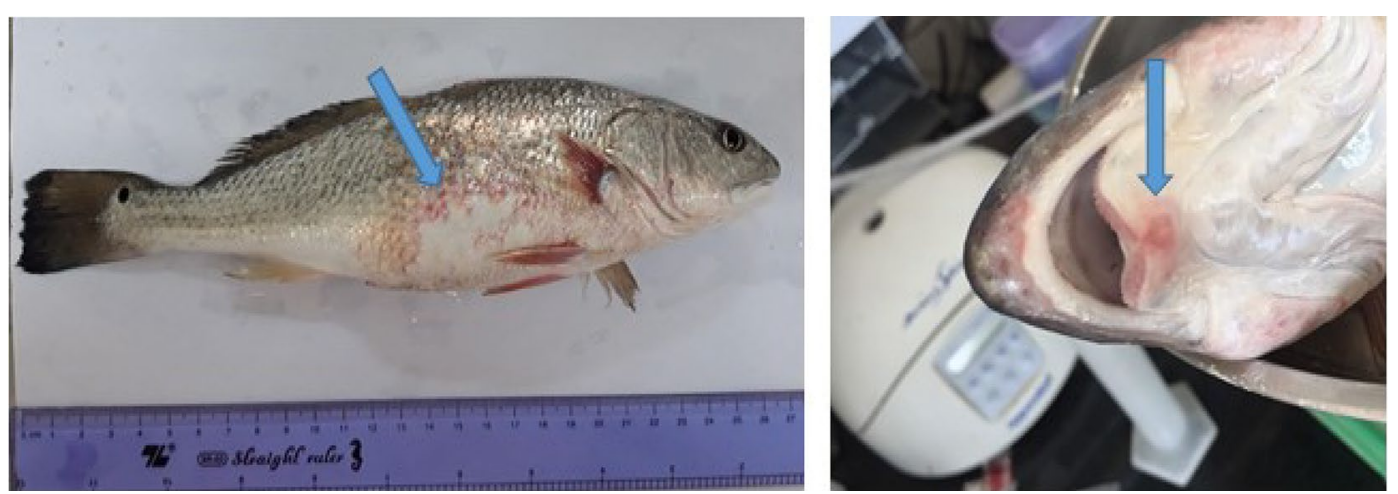

Fig. 1 Sample of Sciaenops ocellatus hemorrhagic signal 
Table 1 Sequence of primers

\begin{tabular}{|c|c|c|c|c|}
\hline Genes & Primer names & Nucleotide sequences $5^{\prime} \rightarrow 3^{\prime}$ & Size (bp) & References \\
\hline \multirow[t]{2}{*}{ toxR } & toxR-F & GTCTTCTGACGCAATCGTTG & \multirow[t]{2}{*}{367} & \multirow{2}{*}{$\begin{array}{l}\text { Luan et al. (2007); Marlina et al. } \\
\text { (2007) }\end{array}$} \\
\hline & toxR-R & ATACGAGTGGTTGCTGTCATG & & \\
\hline \multirow[t]{2}{*}{$T d h$} & $t d h-F$ & GTAAAGGTCTCTGACTTTTGGAC & \multirow[t]{2}{*}{500} & \multirow{2}{*}{$\begin{array}{l}\text { Luan et al. (2007); Marlina et al. } \\
\text { (2007) }\end{array}$} \\
\hline & $t d h-R$ & TGGAATAGAACCTTCATCTTCACC & & \\
\hline \multirow[t]{2}{*}{ Trh } & $\operatorname{trh}-\mathrm{F}$ & TTGGCTTCGATATTTTCAGTATCT & \multirow[t]{2}{*}{269} & \multirow{2}{*}{$\begin{array}{l}\text { Luan et al. (2007); Marlina et al. } \\
\text { (2007) }\end{array}$} \\
\hline & trh-R & CATAACAAACATATGCCCATTTCC & & \\
\hline \multirow[t]{2}{*}{ Th } & th $-\mathrm{F}$ & AAAGCGGATTATGCAGAAGCACTG & \multirow[t]{2}{*}{450} & \multirow{2}{*}{$\begin{array}{l}\text { Luan et al. (2007); Marlina et al. } \\
\text { (2007) }\end{array}$} \\
\hline & th- $\mathrm{R}$ & GCTACTTTCTAGCATTTTCTCTGC & & \\
\hline
\end{tabular}

Tdh, Thermostable direct hemolysin; trh, TDH-related hemolysin; thh, Thermolabile hemolysin; toxR, Toxin operon (Luan et al. 2007; Marlina et al. 2007)

(total volume of $50 \mu \mathrm{L}$ ). PCR amplification was performed in an MJ Mini ${ }^{\mathrm{TM}}$ Thermal Cycler (Bio-Rad, USA) as follows: $94{ }^{\circ} \mathrm{C}$ for $3 \mathrm{~min}$; followed by 30 cycles at $94{ }^{\circ} \mathrm{C}$ for $1 \mathrm{~min}, 50{ }^{\circ} \mathrm{C}$ for $1 \mathrm{~min}$, and $72{ }^{\circ} \mathrm{C}$ for $1 \mathrm{~min}$; and a final cycle of $72{ }^{\circ} \mathrm{C}$ for $7 \mathrm{~min}$. PCR products were used for electrophoresis on a $1 \%$ agarose gel using standard electrophoresis procedures in TAE $1 \mathrm{X}$ buffer with ethidium bromide dye, and electrophoresis images were read by a direct UV reading system (UV-transilluminator, Model: DyNa Light).

\section{S rRNA gene amplification and sequencing}

PCR was performed to amplify the $16 \mathrm{~S}$ rRNA region originating from the genome with a pair of $16 \mathrm{~S}$ primers: $27 \mathrm{~F}$ : AGAGTTTGATCMTGGCTCAG and 1492R: TACGGY TACCTTGTTACGACTT (Jeremy A Frank et al. 2008). PCR was performed on Applied Biosystems-Life Technologies-Thermo Fisher Scientific-USA with a reaction component of $25 \mu \mathrm{l}$ PCR master mix $2 \times(2.4 \mathrm{mM}$ dNTPs each, 0.3 units Taq DNA polymerase), $10 \mathrm{pmol}$ of $27 \mathrm{~F}$ primer, 10 pmol of 1492 primer, $1 \mu$ of total DNA (50 ng/ $\mu \mathrm{l})$ and sterile distilled water to a final volume of $50 \mu \mathrm{l}$. The 16S rRNA gene region was amplified with the following thermal cycle: $95^{\circ} \mathrm{C} / 5 \mathrm{~min}$; 30 cycles $\times\left(95^{\circ} \mathrm{C} / 60 \mathrm{~s}\right.$; $\left.57{ }^{\circ} \mathrm{C} / 50 \mathrm{~s} ; 72{ }^{\circ} \mathrm{C} / 60 \mathrm{~s}\right) ; 72{ }^{\circ} \mathrm{C} / 10 \mathrm{~min}$. Aliquots $(10 \mu \mathrm{l})$ of PCR products were electrophoresed and visualized in $1 \%$ agarose gels using standard electrophoresis procedures in TAE $1 \mathrm{X}$ buffer with ethidium bromide dye, and electrophoresis images were read by a direct UV reading system (UV transilluminator, Model: DyNa Light). Partial 16S rRNA genes of selected isolates in each site were sequenced by MACROGEN, Republic of Korea (dna.macrogen.com). Finally, the $16 \mathrm{~S}$ rRNA sequence of the isolation was compared with that of other microorganisms using BLAST (http://www.ncbi.nlm.nih.gov/ BLAST/Blast.cgi).

\section{Sequencing and analyzing genetic relationships}

The PCR products of the $16 \mathrm{~S}$ rRNA region were purified with Isolate II PCR and Gel (Bioline) kits. Then, they were sequenced directly by the dideoxy termination method on the ABI PRISM ${ }^{\circledR} 3100$ Avant Genetic Analyzer (Applied Biosystems) at Maccrogen Company, Korea (dna.macrogen.com). The nucleotide sequences were arranged based on the Clustals program (Thompson et al. 1997) and edited by using BioEdit 7.0.5 software (Hall 1999). Finally, the $16 \mathrm{~S}$ rRNA sequence of the isolation was compared with that of other microorganisms using BLAST (http://www.ncbi.nlm.nih.gov/BLAST/ Blast.cgi). The DNA polymorphism analysis was based on eight parameters, including the number of separate polymorphic sites (S), total number of mutant sites (Eta), number of haplotypes $(\mathrm{h})$, haplotype diversity $(\mathrm{Hd})$, average number of nucleotide differences $(\mathrm{k})$, and nucleotide diversity $(\mathrm{Pi})$, considered polymorphic measurements in the population (Rozas et al. 2005). Neutrality was tested based on three methods, Tajima's D test (Tajima 1989), $\mathrm{Fu}$ and Li's D* and F* test (Fu and Li 1993) and Fu's (Fu 1995), using DNASP 6.0 software. A phylogenetic tree showing genetic relationships was built by MEGA $\mathrm{X}$ software (Molecular Evolution Genetics Analysis) based on the UPGMA method (Sneath and Sokal 1973). The optimal tree with the sum of branch length equal to 0.08795656 is shown. The percentage of replicate trees in which the associated taxa clustered together in the bootstrap test (1000 replicates) is shown next to the branches (J 1985). The tree was drawn to scale, with branch lengths in the same units as those of the evolutionary distances used to infer the phylogenetic tree. The evolutionary distances were computed using the maximum composite likelihood method (Tamura et al. 2004) and are in units of the number of base substitutions per site. This analysis involved 48 nucleotide sequences. All ambiguous positions were removed for each sequence pair (pairwise deletion option). There were a total of 1434 positions in 
the final dataset. Evolutionary analyses were conducted in MEGA X (Kumar et al. 2018).

\section{Results}

PCR result

The PCR products of the $16 \mathrm{~S}$ rRNA region were purified with Isolate II PCR and Gel (Bioline) kits. Then, they were sequenced directly by the dideoxy terminator method on the ABI PRISM ${ }^{\circledR} 3100$ Avant Genetic Analyzer (Applied Biosystems) at Maccrogen Company, Korea (dna.macrogen.com). The $16 \mathrm{~S}$ rRNA region was approximately $1450 \mathrm{bp}$ for the remaining 30 isolated bacterial strains based on TCBS medium. The BLAST result on NCBI was used to verify and compare with the sequences of the Vibrio spp. with accession number GenBank (Table 2) showed that the nucleotide sequences obtained were highly similar to those of $V$. alginolyticus, $V$. azureus, $V$. fluvialis and V. orientalis, ranging from 98,05 to $100 \%$ (Table 2).

The results indicated that all PCR products of the $16 \mathrm{~S}$ rRNA region in the 30 isolated bacterial strains based on medium TCBS showed a single band with a $100 \%$ amplification rate. All samples gave high DNA concentrations and are clearly seen. The obtained size was approximately $1.500 \mathrm{bp}$, which is in line with the initial expected size (Fig. 2).

Table 2 Phylogenetic affiliation of isolates on the basis of $16 S$ rRNA gene sequences by using the BLAST program in the GenBank database based on sequence similarity and determination of toxin genes

\begin{tabular}{|c|c|c|c|c|c|c|c|c|}
\hline \multirow[t]{2}{*}{ No } & \multirow[t]{2}{*}{ Isolated } & \multirow[t]{2}{*}{ Genbank code } & \multirow[t]{2}{*}{ GenBank reference } & \multirow[t]{2}{*}{ Similarity (\%) } & \multicolumn{4}{|c|}{ Genes } \\
\hline & & & & & toxR & $t d h$ & trh & $T / h$ \\
\hline 1 & Vibrio alginolyticus strain $\mathrm{YHTH7}$ & MT953948 & MN874162.1 & 98.06 & - & - & + & - \\
\hline 2 & Vibrio azureus strain YVL11 & MT953949 & KT986135.1 & 100 & - & - & - & - \\
\hline 3 & Vibrio azureus strain $\mathrm{HTH} 12$ & MT953950 & KT986135.1 & 100 & - & - & - & - \\
\hline 4 & Vibrio alginolyticus strain YN14 & MT953951 & MH298564.1 & 98.05 & + & - & - & + \\
\hline 5 & Vibrio fluvialis strain YHTH16 & MT953952 & СР051126.1 & 100 & + & - & - & + \\
\hline 6 & Vibrio alginolyticus strain YVL22 & MT953953 & MN843961.1 & 99.72 & + & - & + & + \\
\hline 7 & Vibrio alginolyticus strain YVL24 & MT953954 & MN938185.1 & 99.86 & + & + & - & + \\
\hline 8 & Vibrio alginolyticus strain YVL26 & MT953955 & СР051109.1 & 99.59 & - & - & - & - \\
\hline 9 & Vibrio orientalis strain YVL27 & MT953956 & MN945276.1 & 100 & - & - & - & + \\
\hline 10 & Vibrio alginolyticus strain YN34 & MT953957 & MN938360.1 & 99.65 & - & - & + & + \\
\hline 11 & Vibrio azureus strain YVL5 & MT953958 & KT986135.1 & 100 & - & - & + & - \\
\hline 12 & Vibrio azureus strain HTH6 & MT953959 & KT986135.1 & 100 & + & - & - & + \\
\hline 13 & Vibrio fluvialis strain YHTH18 & MT953960 & СР051126.1 & 100 & + & - & + & - \\
\hline 14 & Vibrio alginolyticus strain YN19 & MT953961 & MH298564.1 & 98.05 & + & - & - & + \\
\hline 15 & Vibrio alginolyticus strain YN29 & MT953962 & MN843961.1 & 99.72 & - & - & - & + \\
\hline 16 & Vibrio alginolyticus strain YVL31 & MT953963 & MN938185.1 & 99.86 & - & - & + & + \\
\hline 17 & Vibrio alginolyticus strain YVL40 & MT953964 & СР051109.1 & 99.59 & + & - & - & + \\
\hline 18 & Vibrio alginolyticus strain YVL43 & MT953965 & MN938360.1 & 99.65 & + & - & - & - \\
\hline 19 & Vibrio orientalis strain YVL42 & MT953966 & MN945276.1 & 100 & + & - & + & + \\
\hline 20 & Vibrio alginolyticus strain $\mathrm{YHTH} 44$ & MT953967 & MN874162.1 & 98.06 & + & - & + & + \\
\hline 21 & Vibrio azureus strain YVL45 & MT953968 & KT986135.1 & 100 & + & - & - & + \\
\hline 22 & Vibrio azureus strain YVL46 & MT953969 & KT986135.1 & 100 & - & - & + & - \\
\hline 23 & Vibrio fluvialis strain YHTH47 & MT953970 & CP051126.1 & 100 & - & - & - & - \\
\hline 24 & Vibrio azureus strain YVL33 & MT953971 & KT986135.1 & 100 & + & + & - & - \\
\hline 25 & Vibrio azureus strain YHTH35 & MT953972 & KT986135.1 & 100 & - & - & - & + \\
\hline 26 & Vibrio fluvialis strain YHTH37 & MT953973 & СР051126.1 & 100 & - & - & - & + \\
\hline 27 & Vibrio alginolyticus strain YN38 & MT953974 & MH298564.1 & 98.05 & + & - & - & + \\
\hline 28 & Vibrio alginolyticus strain YVL84 & MT953975 & MN843961.1 & 99.72 & - & - & - & - \\
\hline 29 & Vibrio alginolyticus strain YVL85 & MT953976 & MN938185.1 & 99.86 & - & - & - & + \\
\hline 30 & Vibrio alginolyticus strain YVL86 & MT953977 & СР051109.1 & 99.59 & + & - & - & - \\
\hline
\end{tabular}

Tdh, Thermostable direct hemolysin; trh, TDH-related hemolysin; $t / h$, Thermolabile hemolysin; tox , Toxin operon

GenBank registration Code No: MT953948[ACCN]: MT953977[ACCN]; https://submit.ncbi.nlm.nih.gov/subs/?search=SUB8088865 


\section{Determination of toxin gene}

The agarose gel electrophoresis of PCR products determined the presence of the trh, $t d h, t l h$ and toxR genes at bands $269 \mathrm{bp}, 500 \mathrm{bp}, 450 \mathrm{bp}$ and $367 \mathrm{bp}$, respectively (Fig. 2). We found that 25/30 strains of Vibrio contained at least 1 toxic gene, whereas 5 isolates carried 3 toxin genes. However, none of these isolates consisted of all virulence toxin genes (Table 2). The results clearly indicated the presence of virulence toxins (trh, $t d h$ and $t h$ ) and a regulator toxin (tox $R$ ). Among them, 18 isolates presented $t$ lh, while only 2 isolates were found to carry $t d h$ gen.

\section{Sequencing and analyzing genetic relationships}

Six parameters, including the number of polymorphic sites (S), total number of mutant sites (Eta), number of haplotypes (h), haplotype diversity (Hd), average number of nucleotide differences $(\mathrm{k})$, and nucleotide diversity (Pi), were used to evaluate the diversity of the 30 studied Vibrio strains. As shown in Table 4, ninety-eight separate polymorphic positions (S) created 103 mutant positions (Eta) shown in 30 studied bacterial strains. Vibrio were classified into nine types of haplotypes (h) with a haplotype diversity coefficient accounting for $0.887 \pm 0.032$ $(\mathrm{Hd})$, an average number of nucleotide differences of $25.789(\mathrm{k})$, and a nucleotide diversity coefficient of $17.980 \times 10^{-3} \pm 0.003(\mathrm{Pi})$. All indicators were processed with statistical significance $p<0,05$. The $\mathrm{G}+\mathrm{C}$ content above 1434 site positions of nucleotide sequences accounted for 0.542 (Table 3). Three methods, namely, Tajima's D test, Fu and Li's $\mathrm{D}^{*}$ and $\mathrm{F}^{*}$ test, and Fu's Fs, were used to test neutrality.

The results in Table 4 indicated that a negative Tajima's D signifies an excess of low-frequency polymorphisms compared with the initial expectation (statistical significance: not significant, $p>0.10$ ). Meanwhile, a positive value of $F_{S}(13.659)$ is evidence for a deficiency of alleles, as would be expected from a recent population bottleneck (Strobeck's S statistic: 0.000). In addition, Fu and Li's $\mathrm{F} *$ (statistical significance $0.10>p>0.05$ ) and the value of $\mathrm{Fu}$ and Li's $\mathrm{D}^{*}$ (statistical significance: **, $P<0.02$ ) both yielded positive results, which showed that the evolution of the 30 studied bacterial strains in the Vibrio population was balancing selection and sudden contraction; in other words, rare alleles appeared in populations with low frequency, and the studied population had very few individuals showing large differences in comparison with other individuals in the population (Table 4). The phylogenetic tree shows the genetic relationship of thirty Vibrio strains isolated from three different parts of the fish (S. ocellatus)

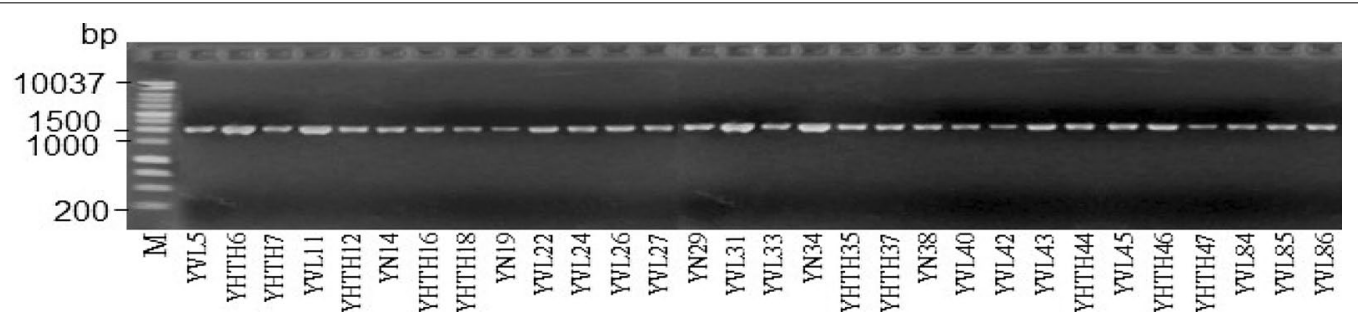

Fig. 2 Electrophoresis of PCR product. M: DNA mass scale (HyperLadder ${ }^{\mathrm{TM}} 1$ kb (200 bp to 10,037 bp), Bioline, Meridian Bioscience

Table 3 DNA diversity based on the 16S rRNA region of the bacterial Vibrio population using the DNASp 5.0 program (Rozas and Rozas 2005)

\begin{tabular}{llllllll}
\hline Genetic region & S & Eta & H & G + C content (1434 sites) & Hd & K & Pi $\left(\times \mathbf{1 0}^{-\mathbf{3}}\right)$ \\
\hline 16S rRNA & 98 & 103 & 9 & 0.542 & $0.887 \pm 0.032$ & 25.789 & $17.980 \pm 0.003$
\end{tabular}

$\mathrm{S}$, Number of variable sites; Eta, Total number of mutations; $\mathrm{H}$, Number of haplotypes; $\mathrm{Hd}$, haplotype (gene) diversity; $\mathrm{Pi}$, nucleotide diversity (per site); $\mathrm{k}$, average number of nucleotide differences

Table 4 Neutrality test results based on the 16S rRNA region of the bacterial Vibrio population

\begin{tabular}{lllll}
\hline Genetic region & Tajima's D test & Fu and Li's D* test & Fu and Li's F* test* & Fu's Fs \\
\hline 16S rRNA & -0.03099 & 1.91401 & 1.49643 & 13.659 \\
& Statistical significance: not signifi- & Statistical significance: **, & Statistical significance: Not signifi- & Strobeck's \\
& cant, $P>0.10$ & $P<0.02$ & cant, $0.10>P>0.05$ & 0.000 \\
& & & 0.00 \\
\hline
\end{tabular}


using the UPGMA method. Figure 3, these strains are divided into six groups. Among these, group I includes the strains of isolated Vibrio that are closely related to $V$. azureus. These strains are mainly concentrated in the digestive system and are hemorrhagic. Groups II, III and $\mathrm{V}$ consist of Vibrio strains isolated in 3 different parts (brain, hemorrhagic and digestive system). They are closely related to $V$. alginolyticus. Group 4 includes two strains isolated from the ulcer that are closely related to Vibrio orientalis. Group VI consists of 4 strains, concentrated in the digestive system and having a close genetic relationship with $V$. fluvialis (Fig. 3). As observed, the isolated Vibrio on 3 organs of red drum fish showing signs of hemorrhagic bleeding were $V$. azureus $(27,67 \%)$, $V$. alginolyticus (50\%), V. orientalis $(6,67 \%)$ and $V$. fluvialis $(16,67 \%)$.

\section{Discussion}

In this study, we isolated 30 strains of Vibrio from three different organs (brain, hemorrhagic site and digestive tract) of $S$. ocellatus. The results showed that the nucleotide sequence $16 \mathrm{~S}$ rRNA regions are highly similar to those of $V$. alginolyticus, $V$. azureus, $V$. fluvialis and $V$. orientalis published in GenBank, ranging from 98.05 to $100 \%$. The digestive system has the most common Vibrio species ( $V$. alginolyticus, $V$. azureus). None of the $V$. parahaemolyticus species were present in the samples, and the same report identified that Vibrio species were isolated from cultured olive flounder (Paralichthys olivaceus) on Jeju Island, South Korea, and none of the V. parahaemolyticus species were also present (Sohn et al. 2019), as reported by (Quang et al. 2020). The V. parahaemolyticus strain is a pathogen causing shrimp disease, (Dao et al. 2014), (Khanh et al. 2019).

The presence of toxic genes related to the hemolysin of fish was found in various Vibrio sp. Meanwhile, approximately $50 \%$ of isolates consisted of toxin operon genes. All $V$. parahaemolyticus isolates contained the toxR genes, but the trh gene did not exist in clams (Corbicula moltkiana) (Marlina et al. 2007). Our data confirmed that three isolates carried both toxR and trh genes, including isolates that exhibited high similarity to $V$. fluvialis, $V$. alginolyticus, and $V$. orientalis. $T D H$ is an enzyme that lyses human red blood cells on Wagatsuma blood agar plates, which is referred to as the Kanagawa phenomenon positive. Another toxin produced by Kanagawa phenomenon-negative Vibrio strains is the tdh-related hemoly$\sin (t r h)$ toxin encoded by the trh gene (Al-Othrubi et al. 2011). Thermolabile hemolysin $(t l h)$ is another Vibrio enterotoxin that causes blood cell lysis in infected fish, and $t h$ is encoded by the th gene (Hasrimi et al. 2018). Among the 4 toxin genes ( $t o x R, t d h$, trh and $t h$ ) investigated from Vibrio spp. causing hemorrhagic disease in $S$. ocellatus, the results showed that the frequency of the toxR gene was detected in the 15 isolates using PCR assay, lowest of $t d h$ gene was 2 isolates, trh gene was 9 isolates and the highest of th was 18 isolates using PCR assay. In addition, the frequency of toxin gene occurrence also showed that there were 5/30 Vibrio strains none carrying the toxin gene (code number: YHTH12; YHTH47; YVL11; YVL26 and YVL84), 10/30 strains carrying only 1 toxin gene, $11 / 30$ strains carrying 2 toxin genes and 4 strains carrying 3 toxin genes ( $V$. alginolyticus strain 3-31, code number YHTH44 (toxR, trh and

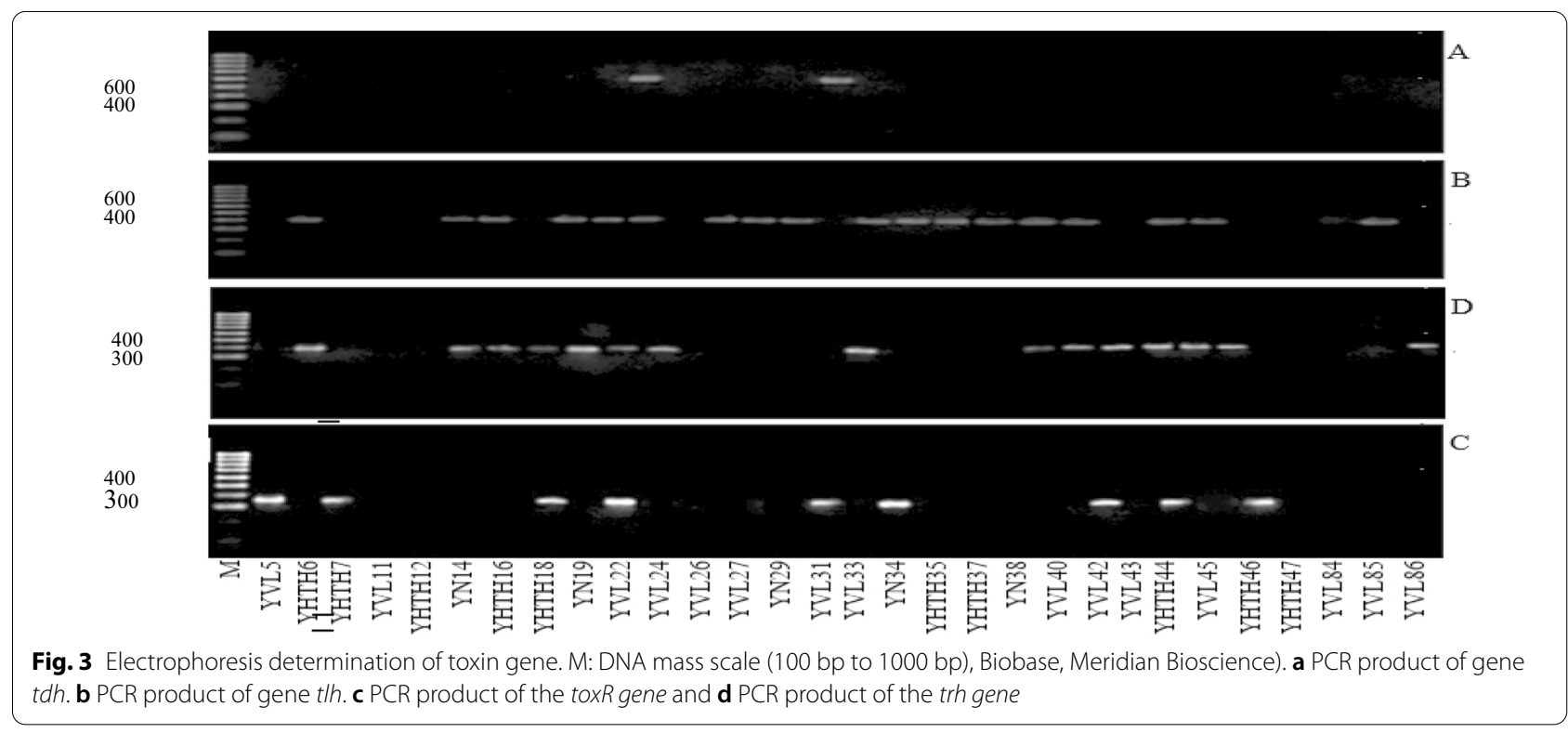


tlh); V. alginolyticus strain 3-31, code number YVL22 (toxR, trh and th); V. alginolyticus strain 3-5, code number YVL24 (toxR, $t d h$ and $t h$ ) and $V$. orientalis strain 5-13, code number YVL42 (toxR, trh and th)). None of Vibrio carried all 4 toxin genes. All Vibrio strains isolated from three marine fish species (S. ocellatus, Lates calcarifer and Epinephelus fuscoguttatus) carried only one $t$ lh gene (Quang et al. 2020). According to Long et al. 2019, we isolated and identified the V. parahaemolyticus 01 strain in Thua Thien Hue Province, Vietnam, causing ulcer disease in S. ocellatus. The full-length thermolabile hemolysin (tlh) gene (1257 bp), encoding the antigen thermolabile hemolysin toxin (tlh) of Vibrio sp. was cloned and sequenced successfully. Sequence analysis of cloned genes showed complete similarity to the V. parahaemolyticus strain (GenBank: AY289609.1) (Long et al. 2019). We further examined the presence of virulence genes homologous to those in $V$. cholerae (toxR, toxS, VPI and ace); toxR was found in $16 \mathrm{~V}$. alginolyticus strains, and toxS was found in 17 strains out of 34. Indicated in two species (Dicentrarchus labrax) and (Sparus aurata). Positive amplification of the virulence pathogenicity island (VPI) was produced by $12 \mathrm{~V}$. alginolyticus strains. Finally, the expected amplification fragment was found in 7 V. alginolyticus isolates. Thus, the pathogenicity of $V$. alginolyticus may be the result of a combination of all these factors (Kahla-Nakbi et al. 2009).

Six parameters were used to evaluate the diversity of the 30 studied Vibrio bacterial strains. The results showed that ninety-eight separate polymorphic positions (S) created 103 mutant positions (Eta) shown in 30 studied Vibrio strains classified into nine types of haplotypes (h) with a haplotype diversity coefficient accounting for $0.887 \pm 0.032(\mathrm{Hd})$, an average number of nucleotide differences of $25.789(\mathrm{k})$, and a nucleotide diversity coefficient of $17.980 \times 10^{-3} \pm 0.003(\mathrm{Pi})$. All indicators were processed with statistical significance $p<0.05$. The $\mathrm{G}+\mathrm{C}$ content above 1434 site positions of nucleotide sequences accounted for 0.542 . Neutrality was tested based on three methods (Tajima's D test, Fu and Li's D* and F* test, Fu's Fs) showing that there was an excess of low frequency polymorphisms relative to expectation, evidence for a deficiency of alleles, as would be expected from a recent population bottleneck and the evolution of the studied 30 Vibrio bacteria population was balancing selection, sudden contraction or in other words, rare alleles appeared in populations with low frequency, the studied population had very few individuals showing large differences in comparison with other individuals in the population. The phylogenetic tree showed the genetic relationship of 30 Vibrio strains using the UPGMA method (bootstrap $=1000$ ) and showed that these strains were divided into six groups. As observed, the isolated Vibrio on 3 hemorrhagic organs of fish (S. ocellatus) were $V$. azureus $(27,67 \%), V$. alginolyticus (50\%), V. orientalis $(6,67 \%)$ and V. fluvialis (16,67\%).

\section{Abbreviations}

PCR: Polymerase chain reaction; TCBS: Thiosulphate citrate bile salt sucrose; th: Thermolabile hemolysin toxin; trh: Tdh-related hemolysin; tdh: Thermostable direct hemolysin; toxR: Toxin operon.

\section{Acknowledgements}

This study was made possible with the technical assistance of Mr. Dang Thanh Long in laboratories who worked at the Institute of Biotechnology, Hue University, Vietnam.

\section{Authors' contributions}

PTHY is PhD student and collected samples, isolated the bacterial strains, used PCR and DNA extraction and first wrote the manuscripts. NDQT is author take care of analysis and data collection, togethor writing MSC. PTHY. NQL, who is main supervisor for all of research steps, data analysis, and consulted the data and writing, final revision and submission to AMBE.

\section{Funding}

The paper was supported financially partly by Hue University and Vietnam Ministry of Education and Training (project code: CT-2018-DHH-07) for submission.

\section{Availability of data and materials}

All the data were presented in the main paper.

\section{Ethics approval and consent to participate}

Samples and animals in this study were allowed by local authorities of Thua Thien Hue province's Department of Fisheries. The research proposal was approved by Hue University's Scientific and Training Committee.

\section{Consent for application}

Not applicable.

\section{Competing interests}

The authors declare that they have no competing interests.

\section{Author details}

${ }^{1}$ University of Agriculture and Forestry, Hue University, Hue 530000, Vietnam. ${ }^{2}$ Institute of Biotechnology, Hue University, Hue 530000, Vietnam.

Received: 24 August 2020 Accepted: 7 December 2020

Published: 4 January 2021

\section{References}

Al-Othrubi SM, Alfizah H, Son R, Humin N, Rahaman J (2011) Rapid detection and E-test antimicrobial susceptibility testing of Vibrio parahaemolyticus isolated from seafood and environmental sources in Malaysia. Saudi Med J 32:400-406

Dang W, Zhang M, Hu Y-H, Sun L (2010) Differential regulation of Sciaenops ocellatus viperin expression by intracellular and extracellular bacterial pathogens. Fish Shellfish Immunol 29(2):264-270. https://doi.org/10. 1016/j.fsi.2010.04.015

Dao NTB, Linh NQ, Khanh N (2014) Research on some characteristics of Vibrio parahaemolyticus which causes EMS disease on juvenile shrimp at Dien Huong community, Phong Dien district, Thua Thien Hue, Vietnam. Hue Univ J Sci. 13-22.

Eldar A, Perl S, Frelier P, Bercovier H (1999) Red drum Sciaenops ocellatus. mortalities associated with Streptococcus iniae infection. Diseases Aquatic Organisms 36(2):121-127. https://doi.org/10.3354/dao036121

Felsenstein J (1985) Confidence limits on phylogenies: an approach using the bootstrap. Evolution 39:783-791. https://doi.org/10.1111/j.1558-5646. 1985.tb00420.x 
Frank JA, Reich Cl, Sharma S, Weisbaum JS, renda A Wilson, \& Olsen, G. J. (2008) Critical evaluation of two primers commonly used for amplification of bacterial 16S rRNA genes. Appl Environ Microbiol 74(8):2461-2470. https://doi.org/10.1128/AEM.02272-07

Fu Y-X (1995) Statistical properties of segregating sites. Theor Popul Biol 48(2):172-197. https://doi.org/10.1006/tpbi.1995.1025

Fu Y-X, Li W-H (1993) Statistical tests of neutrality of mutations. Genetics 133(3):693-709

Hall TA (1999) BioEdit: a user-friendly biological sequence alignment editor and analysis program for Windows 95/98/NT. Paper presented at the Nucleic acids symposium series. https://www.academia.edu/2034992/ BioEdit_a_user-friendly_biological_sequence_alignment_editor_and_ analysis_program_for_Windows_95_98_NT

Hasrimi AN, Budiharjo A, Jannah SN (2018) Detection of th and tdh genes in Vibrio parahaemolyticus inhabiting farmed water ecosystem used for $L$. Vannamei aquaculture. J Phys Conf Ser 1025:1-9. https://doi.org/10.1088/ $1742-6596 / 1025 / 1 / 012058$

Janda JM, Newton AE, Bopp CA (2015) Vibriosis. Clin Lab Med 35(2):273-288

Kahla-Nakbi AB, Chaieb K, Bakhrouf A (2009) Investigation of several virulence properties among Vibrio alginolyticus strains isolated from diseased cultured fish in Tunisia. Dis Aquatic Organisms 86(1):21-28. https://doi. org/10.3354/dao02091

Khanh NV, Linh NQ, Lan TT, Vân TQK, Cờ NTK, Dung TQ (2019) Isolation and screening of Vibrio parahaemolyticus strains to cause acute hepatopancreatic necrosis disease in white-leg shrimps cultured in Phong Dien, Thua Thien Hue, Vietnam using $16 \mathrm{~S}$ rRNA marker. Hue Univ J Sci Nat Sci. 128(1E):47-58. https://doi.org/10.26459/hueuni-jns.v128i1E.5443

Kumar S, Stecher G, Li M, Knyaz C, K., T. (2018) MEGA X: molecular evolutionary genetics analysis across computing platforms. Mol Biol Evol 35:15471549. https://doi.org/10.1093/molbev/msy096

Long DT, Hoang NT, Hong HTK, Yen PTH, Chuong HV, Trang NTQ, Hiep NV (2019) Isolation and DNA cloning of thermolabile hemolysin gene of Vibrio bacteria from Sciaenops ocellatus in Thua Thien Hue, Vietnam. Hue Univ J Sci Nat Sci 128(1E):5-14. https://doi.org/10.26459/hueuni-jns.v128i $1 \mathrm{E} .5373$

Luan XY, Chen JX, Zhang XH, Jia JT, Sun FR, Li (2007) Comparison of different primers for rapid detection of Vibrio parahaemolyticus using the polymerase chain reaction. Lett Appl Microbiol 44(3):242-247. https://doi.org/10. 1111/j.1472-765X.2006.02074.X

Marlina RS, Kqueen CY, Napis S, Zakaria Z, Mutalib SA, Nishibuchi M (2007) Detection of tdh and trh genes in Vibrio parahaemolyticus isolated from Corbicula moltkiana prime in West Sumatera, Indonesia. Southeast Asian J Trop Med Public Health 38:349-355

Mmanda FP, Zhou S, Zhang J, Zheng X, An S, Wang G (2014) Massive mortality associated with Streptococcus iniae infection in cage-cultured red drum (Sciaenops ocellatus) in Eastern China. Afr J Microbiol Res 8(16):17221729. https://doi.org/10.5897/AJMR2014.6659

Neumann B, r., Pospiech, A., \& Schairer, H. U. (1992) Rapid isolation of genomic DNA from gram-negative bacteria. Trends Genetics 8(10):332-333. https://doi.org/10.1016/0168-9525(92)90269-A

Quang HT, Lan TT, Hai TT, Yen PT, Van TQ, Tung HT, Binh MN, Son NK, Linh NQ, Tram ND (2020) Genetic diversity and toxic genes analysis of Vibrio spp. isolated from white leg shrimp and marine fishes cultured in Tam Giang lagoon in Thua Thien Hue province, Vietnam. Indian J Sci Technol. 13(13):1412-22. https://doi.org/10.17485/IJST/v13i13.161

Rozas J, Rozas R (2005) DnaSP version 4.1: an integrated program for molecular population genetics and molecular evolution analysis. Bioinformatics 15:174-175. https://doi.org/10.1093/bioinformatics/15.2.174

Sneath P, Sokal R (1973) Numerical taxonomy. The principle and practice of numberical classification. WH Freeman and Co. San Francisco. pp. 263-268. https://www.jstor.org/stable/2412767?seq=1

Sohn H, Kim J, Jin C, Lee J (2019) Identification of Vibrio species isolated from cultured olive flounder (Paralichthys olivaceus) in Jeju Island South Korea. Fisheries Aquatic Sci 22(1):14. https://doi.org/10.1186/s41240-019-0129-0

Tajima F (1989) Statistical method for testing the neutral mutation hypothesis by DNA polymorphism. Genetics 123(3):585-595

Tamura K, Nei M, Kumar S (2004) Prospects for inferring very large phylogenies by using the neighbor-joining method. Proc Natl Acad Sci U S A 101(30):11030-11035. https://doi.org/10.1073/pnas.0404206101

Thompson JD, Gibson TJ, Plewniak F, Jeanmougin F, Higgins DG (1997) The CLUSTAL_X windows interface: flexible strategies for multiple sequence alignment aided by quality analysis tools. Nucleic Acids Res 25(24):48764882. https://doi.org/10.1093/nar/25.24.4876

Zhang M, Sun L (2011) The tissue factor pathway inhibitor 1 of Sciaenops ocellatus possesses antimicrobial activity and is involved in the immune response against bacterial infection. Dev Comp Immunol 35(3):247-252. https://doi.org/10.1016/j.dci.2010.10.006

\section{Publisher's Note}

Springer Nature remains neutral with regard to jurisdictional claims in published maps and institutional affiliations.

\section{Submit your manuscript to a SpringerOpen ${ }^{\circ}$ journal and benefit from:}

- Convenient online submission

- Rigorous peer review

Open access: articles freely available online

- High visibility within the field

- Retaining the copyright to your article

Submit your next manuscript at $\gg$ springeropen.com 